Estonian Journal of Archaeology, 2022, 26, 1, 27-55

https://doi.org/10.3176/arch.2022.1.02

Margot Laneman

\title{
THE AGE OF THE STONE-CIST GRAVES AT THE LOWER REACHES OF THE PIRITA RIVER RECONSIDERED: ANALYSIS OF THE RADIOCARBON DATA
}

Received 14 June 2021, accepted 16 November 2021, available online 1 February 2022

The area around the lower reaches of the Pirita River in northern coastal Estonia is a unique region where the majority of the known stone-cist cemeteries have been excavated. The number of such cemeteries is seven or eight, with approximately 50 excavated stone mounds. A profound study by Valter Lang in the 1990s, proceeding mainly from artefact finds, dated the stone-cist cemeteries of the area to roughly 600-200 BC, with one exception in 800-500 BC. The current paper summarises and discusses the recently obtained and partly published radiocarbon dates of the skeletons from these sites, including the hitherto unpublished data from Iru 18 and Kuristiku 4. A total of 28 radiocarbon dates has been obtained from nine graves of probably five cemeteries. The numbers are regrettably small, the main reason being the absence of proper excavation and osteological records, which are a prerequisite of consequential and efficient radiocarbon dating. The radiocarbon data suggest that the majority if not all cemeteries had been established between 1100 and 900 or $800 \mathrm{BC}$, and the last graves were added around $400 \mathrm{BC}$ at the latest. A few graves also contained burials from the subsequent centuries. This is consistent with data from stone-cist graves in other regions of Estonia. The discrepancies between the radiocarbon dates and the dates based on artefact typo-chronologies suggest certain caution, although the most likely explanation of the differences lies in the absence of closed find complexes, which has always presented a challenge to the dating of stone-cist graves.

Margot Laneman, Institute of History and Archaeology at the University of Tartu, Ülikooli 18, 50090 Tartu, Estonia; margot.laneman@ut.ee

(C) 2022 Author. This is an Open Access article distributed under the terms and conditions of the Creative Commons Attribution 4.0 International License CC BY 4.0 (http://creativecommons.org/licenses/by/4.0). 


\section{Introduction}

The area around the lower reaches of the Pirita River is, in terms of archaeology, one of the most thoroughly examined regions in Estonia. The closeness and growth of the capital city Tallinn, which by now has swallowed the western villages of the area, has facilitated and necessitated numerous excavations and landscape surveys since the late 19th century. The archaeological sites of the area include a hillock, intermittently inhabited from the Late Neolithic to the end of the Viking Age, contemporaneous or younger open settlements, stone graves of various types and dates, cup-marked stones, and field remains. Most numerous among the monuments are stone-cist graves and cup-marked stones of the Late Bronze or Early Iron Ages (Fig. 1). Roughly two-thirds of the known 70-75 stone-cist graves, clustered in several groups, have been excavated, although with varying quality and extent.

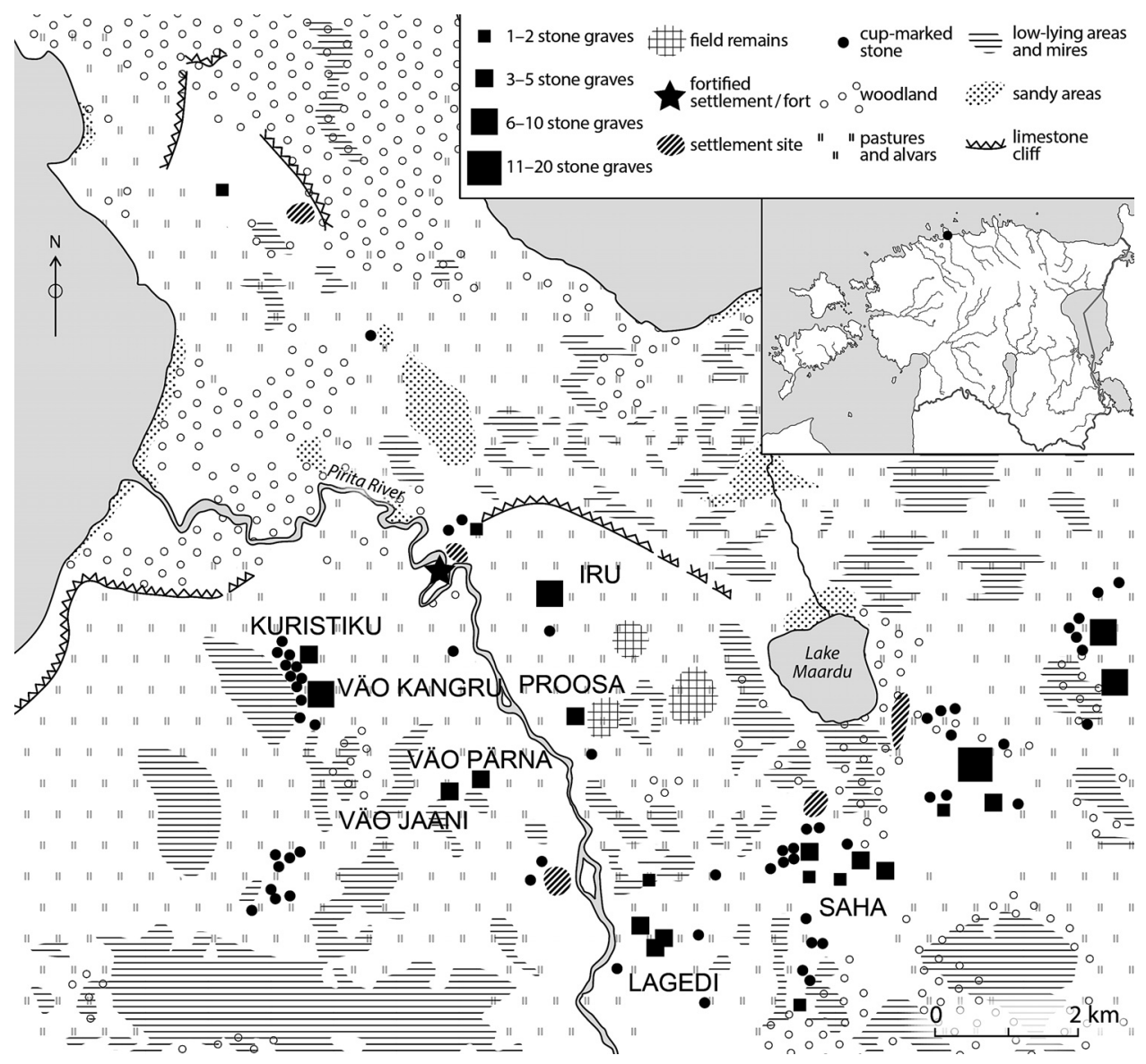

Fig. 1. The area around the lower reaches of the Pirita River in the Bronze and Pre-Roman Iron Ages (adapted from Lang 1996, fig. 102). 
A comprehensive review of the sites and the research, together with an analysis of the settlement and societal structures in the area through the millennia, can be found in Valter Lang's doctoral dissertation (Lang 1996). Also, one of the most notable achievements of this work concerned the chronology of the Bronze and PreRoman Iron Ages, including the stone-cist graves as the most numerous monuments of the era and area. Previously, the principles of dating this grave type had been based on Vello Lõugas' dissertation (1970), and included structural features of the cists and presence or absence of burnt bone deposits as important criteria. As a result, the rare graves that contained well-datable bronze items of Scandinavian origin were dated to the Bronze Age from the 9th century BC onwards, whereas the overwhelming majority of the graves clustered around the turn of the eras (see also Jaanits et al. 1982, 149-150, 184). Lang, focusing on the artefact finds, concluded that the stone-cist graves in the Pirita microregion had been built between 800 and $200 \mathrm{BC}$, and those in other regions of (coastal) Estonia between 1100/1000 and $200 \mathrm{BC}$. However, he also ascribed the majority of the graves to the Pre-Roman Iron Age after 500 BC (e.g. Lang 1996, 311, 592).

The artefact assemblages of the stone-cist graves are, however, small, with little variability, and without closed finds, which means that secure chronologies are difficult to build. To further clarify the issues of chronology and burial practices of these poorly datable monuments, in recent years the bones from stone-cist graves have been subjected to radiocarbon dating (Laneman 2012; 2021a; 2021b; Laneman \& Lang 2013; Laneman et al. 2015). However, only a few graves around the Pirita River have been included in this project, despite the seemingly optimal conditions for comprehensive sampling, i.e. the presence of several groups where all survived graves have been excavated. Leaving aside the excavations of the late 19th and early 20th centuries when bones were not collected for future storage, the main reason for the exclusion has been the absence of excavation and osteological records. Many of the graves have been excavated in the 1970s and 1980s by Vello Lõugas, who was notorious for not submitting excavation reports. As for the osteological data, only the number of buried individuals and their lifecycle stages, such as a child, a juvenile, or an adult, have been tabulated for a selection of graves by Leiu Heapost (Lang \& Ligi 1991, table 1). This means that the precondition of meaningful radiocarbon analysis, i.e. the knowledge on what and/or who is being analysed, is rarely met. Some of the difficulties created by the absence of excavation and osteological reports will also be detailed below in this paper. An additional determinant was the unfortunate coincidence that many bone assemblages stored at the archaeological collections of Tallinn University were inaccessible for years because of being packed for moving to a new location. The available research funds, however, could not be put on hold for an indeterminate period until the opening of the new repository.

Owing to these limitations, the grave group in the land of Jaani farm at Väo has been the only one for which relatively extensive radiocarbon dating has been possible so far. In this case, the excavation report was extant and the bones were accessible, and an osteological study was carried out within the radiocarbon dating 
project (Laneman et al. 2015). Further, there are two graves, Iru 18 and Kuristiku 4, where the majority of buried individuals have been radiocarbon dated, mainly to provide reference material for more thoroughly sampled cemeteries elsewhere. This data has not been published before. Additionally, a few individuals from some of the remaining grave groups have been selected for an aDNA study, within which those whose remains contained a sufficient amount of DNA were radiocarbon dated along the way (Saag et al. 2019). The chronological relevance of this data has not been discussed so far.

This paper focuses on this recently collected radiocarbon data. One of the aims is to publish the aforementioned dates from Iru 18 and Kuristiku 4 in all detail to make the information available for further research. The dates published earlier will also be reviewed, and the input of the radiocarbon data to the prevailing knowledge will be discussed. This discussion includes - in my opinion, unavoidably - the analysis of the discrepancies between the radiocarbon dates and the dates based on artefact typo-chronologies, presented in Lang 1996. Unlike some previous works, this study is still valid and relevant today, since neither the dates of the particular cemeteries nor the general principles of dating established therein have recently been discussed to a sufficient degree, let alone explicit contestation or refutation. ${ }^{1}$ Also, in the humanities written word has a long currency and strong credibility, which sometimes keeps outdated information circling for a long time. One such example is the age of the well-known stone-cist graves at Jõelähtme, which in some recent accounts is still based on the absolute chronology used in the 1980s (see Laneman 2021a). The explicit juxtaposition of 'old' and 'new' data, with an attempt to explain the differences, will hopefully curb the tendency and enhance the dissemination of fresh information.

In what follows, I will first portray the stone-cist grave groups one by one, and then I will integrate the information in a broader-scale discussion. Note that all radiocarbon dates quoted in this study have been calibrated with $95.4 \%$ probability by using OxCal v4.4.2 with IntCal20 calibration curve (Bronk Ramsey 2009; Reimer et al. 2020).

\section{The grave groups}

A classic stone-cist grave consists of a ring wall, a two-metre-long, north-south oriented stone cist in the centre, and stones filling the space between the ring wall and the cist. The graves contain the remains of several individuals, mostly but not exclusively in the cists. It is common for the graves to occur in groups. One such group is considered a cemetery of a kin group (Lang \& Ligi 1991; Lang 1996). However, not always are such groups easily definable, which means that establishing a concrete number of cemeteries in an area is difficult. On the other hand, and despite every mound being different in details, a group may possess

${ }_{1}$ Lang has addressed the date of the stone-cist graves also in his later publications (Lang 2007; 2018; 2020), but these are generic works and provide no in-depth analyses of the subject. 
distinctive features, such as multiple ring walls. The brief descriptions below will hopefully illustrate these matters, regardless of unavoidable ambiguity due to gaps in the excavation records.

\section{Iru}

The stone-cist graves at Iru were scattered across an area of ca one square kilometre (Lang 1996, figs 4, 46). Ten graves, some of them re-structured at a later date, had survived until excavation. In prehistory, the graves were probably more numerous and possibly formed several (sub)groups. With two graves excavated earlier (Vassar 1936; 1966, 194), the majority was subjected to rescue excavation in 1974 (Lõugas 1976).

Most of the mounds were ordinary stone-cist graves with a single ring wall 8$12 \mathrm{~m}$ in diameter and a single central cist of stacked limestone slabs. Only grave 6 featured a double ring wall and a cist of upright slabs. The cairns consisted mostly of limestone, although at least some of the ring walls had a foundation of fieldstones of crystalline rock. With several inhumations in a cist being the prevalent and expected burial mode, two cists contained burnt bones along with the inhumed skeletons, and in a few graves, burnt bones were found outside the cist. The osteological review comprises 23-25 inhumations in eight graves (Lang \& Ligi 1991, table 1). Six graves, mostly the cists, contained altogether seven bone pins, which is unusually many. Pottery was present in the majority of the cairns, reportedly both inside and outside the cairns. Unordinary finds were a bronze mount and an iron needle in two of the cists. As usual in stone-cist graves, the finds cannot be associated with particular individuals. Some of the graves contained burials also from the Roman Iron Age (Vassar 1966) or the Viking Age (Lõugas 1976).

Lõugas (1976) dated the graves to the last quarter of the 1st millennium BC, i.e. 250-1 BC. Lang argued that a few of the bone pins and perhaps some of the pottery indicated the end of the Bronze Age and the rest of the finds the Early Pre-Roman Iron Age. Accordingly, and considering the size of the cemetery, he dated the graves to 600-300 BC (Lang 1996, 292).

Radiocarbon dates are available for graves 14 and 18. Both were among the easternmost graves of the group, with a distance of a few hundred metres from one another, and contained pottery outside the cists and bone pin(s) in the cists. Both were the graves for which Lang, on the basis of mainly the pins which he classified as 'atypical spade-headed', preferred a date in the end of the Bronze Age rather than in the Pre-Roman Iron Age, i.e. the 6th century BC (Lang 1996, 285, 292; cf. op. cit., 125). A male from the cist of grave 14 was, however, radiocarbon dated within the aDNA study to $\mathbf{2 8 3 4} \pm \mathbf{2 8}$ BP or 1110-900 BC (Saag et al. 2019). Grave 18, as the reportedly only grave in the group that contained Bronze Age inhumation burials outside the cist, has been subjected to more thorough sampling to chronologically compare the burials of differential placements within a grave. The sampling, however, turned out to be far more complicated than expected even in view of the lacking excavation records. The case deserves a detailed description to provide a 
cautionary example of inconsistencies encountered in the bone assemblages for which there is no proper excavation report and no proper osteological analysis. In retrospect, I tend to think that collecting samples from such assemblages should be avoided. $^{2}$

In his cursory review article (Lõugas 1976), the excavator mentioned two or three inhumed skeletons in the cist, 'a couple' of skeletons next to the cist's western wall, and a few burnt bones in the eastern periphery of the cairn. The anthropological estimation (table 1 in Lang \& Ligi 1991) lists two adults, an adolescent, and a child for the entire grave. Leiu Heapost, the author of the estimation, kindly agreed to extend the information by explaining that the cist contained a middle-aged female and an adolescent male under 20 years old, whereas a child and a youngish adult, perhaps a female, were located outside the cist (pers. comm.). At sampling, however, another bioarchaeologist, Martin Malve, observed that the mature individual was a male and the adolescent was a female; for the remaining burials, his preliminary judgment agreed with that of Heapost. The mature individual has been subjected to an aDNA analysis (Saag et al. 2019) which, unfortunately, was unable to determine the sex of the person.

The things were further complicated by the discovery that the arrangement of the bone assemblage, divided into several sub-assemblages, matched neither the account by Lõugas (1976) nor Heapost (pers. comm.). The majority of the bones have been labelled as originating from the cist, whereas none of the sub-assemblages was unequivocally labelled as coming from outside the cist; some sub-assemblages were entirely unlabelled. The bones have obviously been re-packaged and relabelled in the 21 st century, with no original labels preserved. It seems likely that a mix-up has occurred at some point in time, but the absence of an excavation report makes it impossible to prove.

All things considered, I believe we managed to sample both adults and the adolescent mentioned by Heapost. The cursory examination of the bones at sampling did not detect the child, except for the skull which was decided to be left undamaged. The fourth sample of an inhumed bone, of an adult, came from the only sub-assemblage that had been marked differently than being a cist burial (' $15 / \mathrm{f}-\mathrm{g}$ ') It is therefore likely that these bones had been located outside the cist. The possibility that the bones belonged to the young adult outside the cist is not entirely excluded, although the majority of this individual's remains formed a single distinct assemblage. Considering the unreliability of the available osteological data and the bone distribution patterns in an average stone-cist grave, it is equally possible that the sampled vertebra had belonged to a separate individual. Finally, a cremated bone, burnt at ca $450-750{ }^{\circ} \mathrm{C}$ (M. Malve, pers. comm.), was also radiocarbon dated. The sample details and the results of the analysis are shown in Table 1 and Figure 2.

${ }_{2}$ Iru 18 was one of the first stone-cist graves I sampled for radiocarbon dating. With no model to follow, I was unaware of the accompanying pitfalls. Unfortunately, it happens far too often even in the cases where the excavation and osteological reports are extant that a carefully prepared sampling strategy has to be abandoned, because things on paper and things in the repository look too different. 
Table 1. AMS dates of the bones from stone-cist grave 18 at Iru. Calibration after OxCal v4.4.2 with the IntCal20 calibration curve (Bronk Ramsey 2009; Reimer et al. 2020). In all samples, collagen was radiocarbon dated. The stable isotope ratios were measured with IRMS method with the uncertainty of \pm 0.1 , unless stated otherwise; $\mathrm{C}: \mathrm{N}$ ratios were not reported by the laboratory. $\mathrm{L}$ - left; $\mathrm{R}$ - right; Hela - Laboratory of Chronology, Finnish Museum of Natural History

\begin{tabular}{|c|c|c|c|c|c|c|c|}
\hline Context & Individual & Bone & $\begin{array}{l}\text { Lab code } \\
\text { Hela- }\end{array}$ & Date BP & $\begin{array}{c}\text { Date cal BC } \\
(95.4 \%)\end{array}$ & $\begin{array}{l}\delta^{13} \mathrm{C} \\
(\% 0)\end{array}$ & $\begin{array}{l}\delta^{15} \mathrm{~N} \\
(\%)\end{array}$ \\
\hline$\overline{\text { Cist }}$ & Mature adult & L humerus & 2413 & $2595 \pm 30$ & $820-590$ & -21.3 & N/A \\
\hline Cist & Adolescent & R ulna & 2415 & $2464 \pm 30$ & $760-410$ & -21.4 & 9.9 \\
\hline Outside cist? & Adult & L humerus & 2414 & $2165 \pm 30$ & $360-60$ & -21.4 & $9.9 \pm 0.2$ \\
\hline $\begin{array}{l}15 / \mathrm{f}-\mathrm{g}, \\
\text { outside cist? }\end{array}$ & Adult & Vertebra & 2416 & $2679 \pm 30$ & $900-790$ & -17.9 & $10.2 \pm 0.2$ \\
\hline $\begin{array}{l}\text { Outside cist, } \\
\text { cremation }\end{array}$ & N/A & $\begin{array}{l}\text { Tubular } \\
\text { bone }\end{array}$ & 2417 & $2566 \pm 30$ & $810-560$ & -21.5 & N/A \\
\hline
\end{tabular}

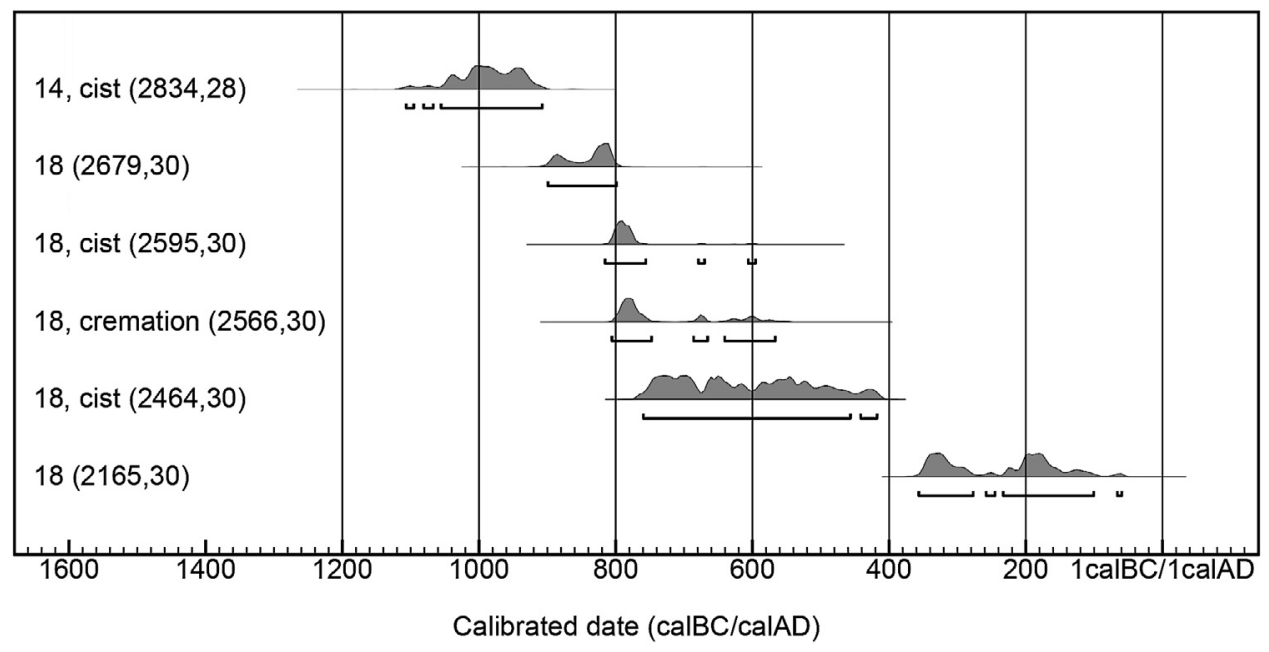

Fig. 2. AMS dates of the human bones from stone-cist graves 14 and 18 at Iru, corrected to calendar ages by OxCal v4.4.2 with the IntCal20 calibration curve (Bronk Ramsey 2009; Reimer et al. 2020). The figure shows $95.4 \%$ probability ranges. The date from Iru 14 was first published in Saag et al. 2019.

The obtained radiocarbon determinations, converted to calendar dates, span from 900 to $60 \mathrm{BC}$. It seems that the grave had been erected around $800 \mathrm{BC}$ at the latest and the last burial had been interred centuries later in the Pre-Roman Iron Age. The true distribution of burials within the period is difficult to establish because of several factors. First, the seemingly oldest date, Hela-2416, is not entirely reliable. Although the associated carbon isotope measurement is not necessarily outside acceptable limits (see e.g. Mook \& Waterbolk 1985, 40), it is notably different from the remaining $\delta^{13} \mathrm{C}$ figures. Therefore, a reservoir effect that shows the bone older 
than it is, cannot be ruled out. ${ }^{3}$ Also, radiocarbon dates of burnt bone should be treated with caution, as such bones are susceptible to contamination by external carbon reservoirs during the cremation or after deposition (see Van Strydonck et al. 2009; Snoeck et al. 2014; Van Strydonck 2016; Minami et al. 2019). The reliability of the date in question cannot be tested, since firmly associated finds are lacking and the mode of burial reveals nothing about the date of burial. Next, one of the cist burials yielded a date stretching across the entire Hallstatt plateau of the calibration curve, and there is no evidence to narrow the span. The same applies to the probably latest burial of the grave. Without radiocarbon dating the rest of the cemetery to a comparable extent, it remains unknown whether this individual was one of the latest interments of continuous burial that began in the Bronze Age or someone placed in an old cairn after a considerable interlude. Although similar cases, i.e. Pre-Roman Iron Age burials in stone-cist graves, are not particularly rare (Laneman 2012; 2021b), they are all inconclusive in regard to this question.

\section{Kuristiku}

The four stone-cist graves at Kuristiku were rescue excavated in 1980 (Lõugas 1981). Unlike at Iru, the group was compact and undoubtedly formed a single cemetery (Fig. 3; Lang 1996, pl. XLII). Unfortunately, all graves were more or less damaged. Where observable, they had two concentric ring walls of limestone above a crystalline rock foundation, the exterior circles 9-14 $\mathrm{m}$ in diameter, and a single cist, which at least in the case of grave 2 had been built of stacked limestone, and in the case of grave 4, of other types of fieldstones. Heapost counted seven inhumations in three of the graves (Lang \& Ligi 1991, table 1). Besides inhumations, burnt bones were present in at least two of the cairns. Graves 1-3 contained a bone pin each, and small quantities of pottery were recorded in all graves apart from no. 2. Lõugas (1981) placed the graves to the end of the 1 st millennium BC. Lang $(1996,293)$ argued that the cemetery dated from roughly 500-350 BC. His estimation is mainly based on two of the bone pins, which he classified as variant 3 of the spade-headed pins and an atypical specimen, respectively (Lang 1996, 144, 293).

The initial plan was to sample the whole group for radiocarbon dating. At sampling, however, it became clear that the bones of grave 1 were not present in the repository and grave 3 had been too damaged to yield authentic contexts. The bone assemblage of the best-preserved grave, no. 2, did not match the descriptions by Lõgas (1981) and Heapost (Lang \& Ligi 1991, table 1) and was thus also

\footnotetext{
3 In case the date is an indication of true age, it implies that the area outside the cist may have contained remains of more than one inhumed adult, and the burial may have pre-dated the cist burials. If it did, it could have been either an originally cist burial that had been removed from the cist to make room for new bodies, a secondary deposition of bones, or an individual who was the first to be interred in the grave but had been considered ineligible for a cist burial. Similar cases have been observed elsewhere (Laneman \& Lang 2013; Laneman 2021a). However, one should not forget that the case discussed here involves a large amount of guesswork.
} 


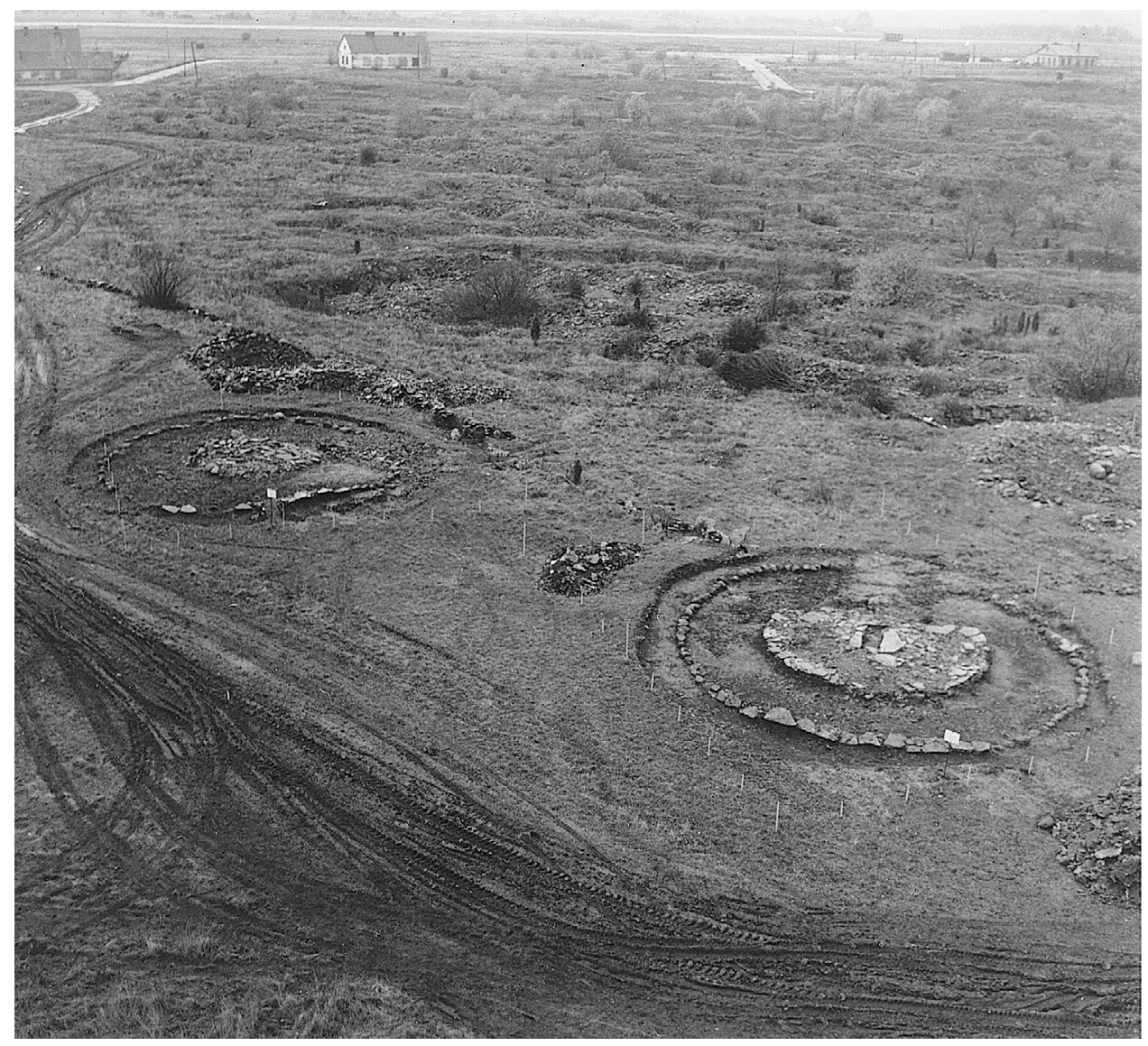

Fig. 3. Stone-cist graves at Kuristiku in 1980 (photo: Rein Kärner; Archaeological Research Collection at Tallinn University, archive, f 17). In the foreground are graves 1 (left) and 2; grave 4 is partly visible on the right.

rejected as contextually unreliable. Radiocarbon dates are therefore available only for grave 4.

Unfortunately, the center of this grave, including the cist, had been severely damaged (Lang 1996, pl. XLIII). The excavator (Lõugas 1981) mentioned both inhumed and burnt bones at where the cist had once been, and a considerable amount of unburnt bones in the north-eastern periphery of the grave, outside the ring walls. Two bracelets of the 4 th -5 th centuries $\mathrm{AD}$, found near the bones, suggested a Roman Iron Age date for the peripheral burials (Lõugas 1981; Lang 1996, 144). Heapost (Lang \& Ligi 1991, table 1) listed two children and an adult for this grave. The cursory examination at sampling by Martin Malve, however, revealed the presence of more skeletons. The peripheral bone assemblage included the remains of at least a child and an aged male, and the unlabelled bones that had 
most likely been collected from the cist area had belonged to another child and a young adult. All of the mentioned individuals were sampled for radiocarbon dating (Table 2). However, there may have been more deceased in the grave. Contrary to what had been reported by the excavator, the assemblage contained no burnt bones. On the other hand, the excavator did not mention burnt bones in grave 2, but they were nevertheless present in the respective assemblage. It is difficult to assess whether the mistakes lie with Lõugas' superficial review (1981) or procedures such as the osteological examination or curation of the assemblage.

The calibrated radiocarbon dates range from ca 900 to $400 \mathrm{BC}$, some of them spanning the Hallstatt plateau (Fig. 4). Assuming that secondary burial of 'old' bones has not been practised, the grave must have been present around $800 \mathrm{BC}$ at the latest. The time of the last burials within the indicated period is, however, impossible to ascertain. That much is clear that the hypothesis of the peripheral burial(s) being from the Roman Iron Age was not confirmed; admittedly, it was not conclusively refuted either. Moreover, the damaged state of the grave casts doubt on the view

Table 2. AMS dates of the bones from stone-cist grave 4 at Kuristiku. Calibration after OxCal v4.4.2 with the IntCal20 calibration curve (Bronk Ramsey 2009; Reimer et al. 2020). In all samples, collagen was radiocarbon dated. The stable isotope ratios were measured with IRMS method. UBA-14Chrono Centre for Climate, the Environment and Chronology, Queen's University Belfast

\begin{tabular}{|c|c|c|c|c|c|c|c|c|}
\hline Context & Individual & Bone & $\begin{array}{l}\text { Lab code } \\
\text { UBA- }\end{array}$ & Date BP & $\begin{array}{c}\text { Date cal BC } \\
(95.4 \%)\end{array}$ & $\begin{array}{l}\delta^{13} \mathrm{C} \\
(\%)\end{array}$ & $\begin{array}{l}\delta^{15} \mathrm{~N} \\
(\% 0)\end{array}$ & $\mathrm{C:N}$ \\
\hline $\begin{array}{l}\text { Outside } \\
\text { cist/grave }\end{array}$ & Adult, male & Tibia & 24136 & $2467 \pm 30$ & $770-420$ & -21.1 & 9.5 & 3.33 \\
\hline $\begin{array}{l}\text { Outside } \\
\text { cist/grave }\end{array}$ & Child & Metacarpal & 24137 & $2675 \pm 42$ & $910-790$ & -21.4 & 10.1 & 3.20 \\
\hline Cist? & Adult & Tubular bone & 24138 & $2441 \pm 35$ & $760-400$ & N/A & N/A & N/A \\
\hline Cist? & Child & Fibula & 24139 & $2557 \pm 31$ & $810-550$ & -20.6 & 9.9 & 3.17 \\
\hline
\end{tabular}

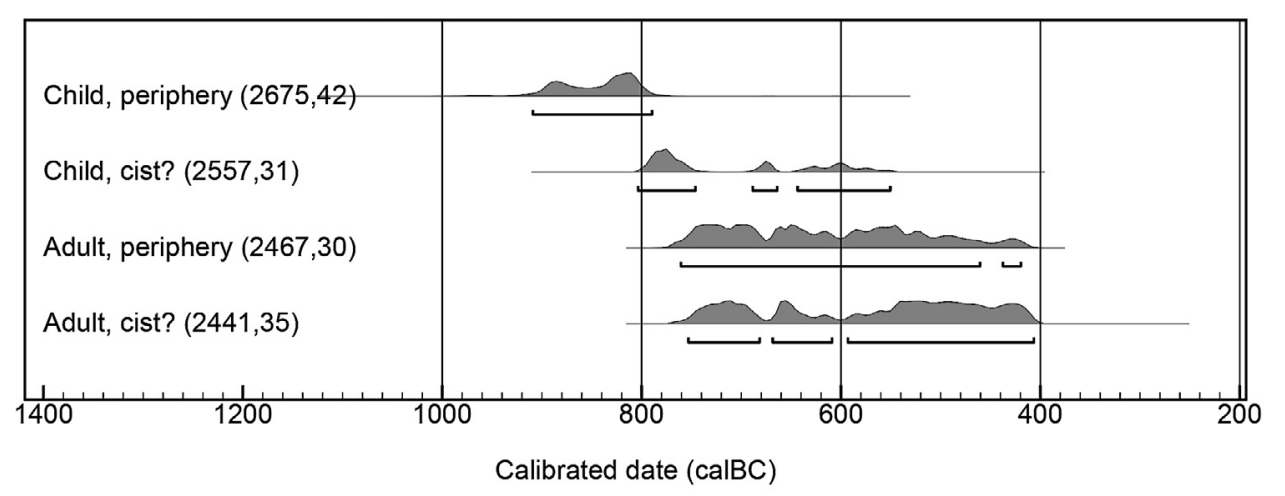

Fig. 4. AMS dates of the human bones from stone-cist grave 4 at Kuristiku, corrected to calendar ages by OxCal v4.4.2 with the IntCal20 calibration curve (Bronk Ramsey 2009; Reimer et al. 2020). The figure shows $95.4 \%$ probability ranges. 
that the area outside the ring walls had been the original burial place of the remains. At grave 1, an apparently similar cluster of bones in the south-eastern part of the grave was interpreted as resulting from the damage done to the site (Lõugas 1981). It cannot be denied that burial outside grave borders has been practised (e.g. Laneman 2012), but such cases are generally rare. As for the bracelets, their presence may have been a result of activities other than burial. The overall conclusion is that with all these things considered, and in the absence of excavation and osteological reports, it is wise to avoid drawing far-reaching conclusions on the basis of this case.

\section{Kangru at Väo}

In the land of Kangru farm in Väo village, $600 \mathrm{~m}$ from the graves of Kuristiku, nine stone-cist graves have been excavated. It was a dense group of five cairns in a tight row, with the remaining four scattered at a distance of 80-150 metres from the core cluster (Lang 1996, fig. 51). The group was rescue excavated simultaneously with the cemetery at Kuristiku (Lõugas 1981), except for two graves that had been excavated earlier (Vassar 1959; Jaanits \& Lavi 1978; see also Tõnisson $\&$ Selirand 1964, 229). Characteristic of the group were double ring walls with crystalline rock foundations and upper parts of limestone in at least the exterior circles, and a single cist formed of upright limestone slabs. However, there were deviations: two graves (nos. 3a and 8) had two cists, at least one grave (no. 8) had cists made of stacked limestone slabs, and the smallest grave (no. 3a) had a single ring wall, $4 \mathrm{~m}$ in diameter. The exterior ring walls of the other graves were mostly 9-16 $\mathrm{m}$ across. Besides inhumations in the cists, burnt bones and inhumations outside the cists were observed in graves 1 and 8 , which had been excavated before 1980. The presence of similar burials in the remaining graves cannot be ruled out, despite the fact that Lõugas (1981) does not mention it. Heapost listed 13 inhumations in five graves (Lang \& Ligi 1991, table 1). As for the artefact finds, the cist of grave 4 contained an unlikely combination of a bronze razor (Fig. 5), a bone pin, an iron shepherd's crook pin, and some potsherds. The grave, as many of

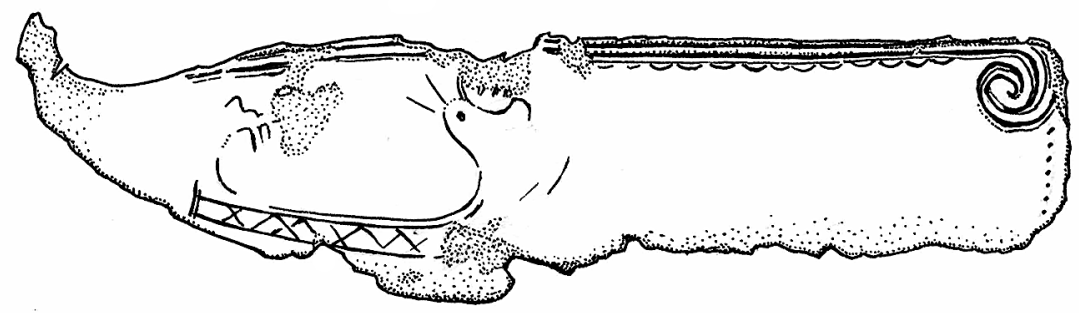

Fig. 5. Bronze razor from grave 4 at Kangru, Väo (AI 5080: 39; drawing by Kersti Siitan). 
the other graves in the group, had been severely damaged, which means that the iron pin with its Pre-Roman Iron Age date was possibly a later addition to the cist. A bone pin was also present in the secondary cist of grave 8 . Pottery and a few other nondescript items were recorded outside the cists in both graves 4 and 8 as well as in some of the other cairns.

Lõugas (1981) dated the cemetery to the end of the 1st millennium BC. According to Lang $(1996,293)$, the cemetery was used from 800 to $500 \mathrm{BC}$. He was relying first and foremost on the bronze razor with well-datable counterparts in the Nordic Bronze Age assemblages, although the above-mentioned spade-headed bone pins in graves 4 and 8 (variants 1 and 3, respectively) and pottery in grave 8 (type BII:b) were also considered.

Radiocarbon dates are available for two males included in the aDNA study (Saag et al. 2019). A male from the cist of grave 1 was radiocarbon dated to $\mathbf{2 8 3 4} \pm \mathbf{2 6} \mathbf{B P}$ (1100-900 BC) and a male from one of the cists in grave 8 to $2732 \pm 28$ BP (930$810 \mathrm{BC})$. Unfortunately, the absence of detailed excavation records and unclear labelling of the bones do not allow ascertaining in which of the two cists the latter male had been interred.

A few things must be pointed out about the razor of grave 4. Lang (1996, 140$141,293,562)$ is of the opinion that it represents type XIB4a of Evert Baudou's classic typology (1960) and dates from Period V of the Nordic Bronze Age. Unfortunately, the most important diagnostic feature in terms of the mentioned typology, the handle, is missing, and the type of the razor cannot be ascertained. Decoration alone is not a reliable means for dating, but it is worth noting that the relatively simple style of the image, including a right-sailing ship with probably a horse-shaped stem, is characteristic of Period IV rather than Period V (Kaul 1998; 2018a; 2018b; Sørensen \& Appleby 2018). At least some razors with stylistically similar decoration in Denmark (e.g. Kaul 1998, Cat. no. 30) belong to type XIB2, which date from Period IV or the transitional phase between Periods IV and V (Baudou 1960, 33-34). Either from Period IV or early Period V, the Väo razor probably dates from around $900 \mathrm{BC}$ at the latest (for the Nordic Bronze Age chronology, see e.g. Olsen et al. 2011 or Hornstrup et al. 2012).

\section{Jaani at Väo}

Nearly $2 \mathrm{~km}$ from the Kangru graves, the rescue excavation in the land of Jaani farm in 1982 showed that the apparently single mound, measuring $11 \times 14 \mathrm{~m}$, contained a (half of a) stone-cist grave, which had been tightly fitted between another stone-cist grave and a ship setting (Lang 1983). Both stone-cist graves had a base of crystalline rock fieldstones topped with limestone, a ring wall echoing this structure, and a cist built of stacked limestone. The ship setting featured a frame and a cist of fieldstones and a fill of limestone. The stone-cist graves were badly damaged and the bones, mostly but not exclusively from inhumations, were intermingled to such an extent that only a few articulated skeletons in the cist of the middle grave were observable. Heapost (Lang \& Ligi 1991, table 1) reported eight adults and 13 children 
for the two stone-cist graves. A more thorough examination showed that the bone assemblage included the remains of at least ten adults, two teenagers, 14 children 111 years of age, and 12 infants (Laneman et al. 2015). The possibly original deposit of burnt bones located in the ship had gone missing after excavation. As for the artefacts, the cist finds comprised a bone pin and perhaps also a curved iron knife. The remaining finds included another iron knife, pottery, a bronze shepherd's crook pin, spiral finger rings, and other rather nondescript items from mainly the Roman Iron Age and the following periods.

Lang (1996, 292), basing his reasoning on the presence of a Nordic-type ship setting, a spade-headed bone pin of variant 3 , and a curved iron knife, dated the trio of the graves to ca 500-400 BC or, in case they had been part of a larger grave group (see below), to ca 600-300 BC. He also acknowledged the presence of Late Roman Iron Age burials (op. cit., 138).

The 15 radiocarbon dates (Laneman et al. 2015; Fig. 6) suggested that the cemetery had been established between 820 and $550 \mathrm{BC}$ at the latest. It may have been used for burial also between 550 and $400 \mathrm{BC}$, and most probably was between 400 and $200 \mathrm{BC}$. At least half of the deceased appeared to have been interred at even later dates between AD 50 and 650. It is possible that in the last burial period(s) the site served as a burial ground for predominately subadults, particularly infants.

\section{Pärna at Väo}

The graves on the land of Pärna farm in Väo were situated at a distance of only a few hundred metres from the Jaani graves, which means that both groups may have been built and used by the same community. Since many of the graves had been destroyed before registration, the size and the layout of the cemetery remain unknown. At least four graves have been excavated, three in 1895, probably with no bones collected (Howen 1900), and two in 1972-1973 (Lõugas 1975). ${ }^{4}$ The limited records of the excavations reveal that besides the graves 8-9 $\mathrm{m}$ in diameter, the group included remarkably large cairns 15-22 m across. At least one of the graves featured two ring walls. Cists of stacked as well as vertical limestone slabs were present, and one of the graves excavated in the 19th century contained, in addition to a regular limestone cist, a possibly tarand-like structure of crystalline rock fieldstones, $2.8 \times 1.9 \mathrm{~m}$ in size. At least some of the graves had a base of crystalline rock fieldstones under an upper structure of limestone. The main mode of burial was inhumation in the cists, although the poor recording does not allow excluding the presence of inhumations or cremations outside the cists. Heapost's data comprises only three individuals in grave 1 (Lang \& Ligi 1991, table 1). The cist finds include, reportedly, a clay pot and the tip of a bone pin. The rest of the

${ }^{4}$ Lõugas (1975) suspected that one of the graves he excavated had been already dug in 1895. Lang $(1996,132)$ thinks that Axel von Howen excavated five graves in the Pärna group. Although the account by von Howen (1900) is ambiguous, it seems that two of the graves he examined were situated more than $1.5 \mathrm{~km}$ north of the Pärna group, which suggests that they belonged to another cemetery, perhaps that in the land of Kangru farm. 
find assemblage is mainly made up of pottery and a few decorative metal items of the Iron Age, analogous to those in the Jaani graves.

According to Lõugas (1975), the graves had been built at the end of the 1st millennium BC. Lang (1996, 133, 292), proceeding from the bone pin of grave 2 and the pottery of BII:b type in grave 1 , dated the cemetery to a 250 -year period around the beginning of the Pre-Roman Iron Age. Radiocarbon dating of a male from the cist of grave 1 within the aDNA project (Saag et al. 2019) yielded an earlier date, $2677 \pm 26$ BP $(900-790 \mathrm{BC})$.

A few things must be noted about the diagnostic pottery of grave 1, particularly because pottery, although rare in cists, has had an important role in the stone-cist graves' chronology (see below). According to the excavator (Lõugas 1975), the southern end of the cist in grave 1 contained a small fragmented clay pot, and a few additional potsherds were located in the peripheral areas of the grave. In the find repository, however, none of the pottery finds has been marked as coming from the cist. Lang $(1996,133)$ described a situation opposite to that mentioned by Lõugas: a small potsherd in the cist and two fragmented vessels in other parts of the grave; both vessels are of BII:b type, one of them undecorated (op. cit., fig. 50: 2) and the other decorated with 'impressions of a stamp'. In another passage (op. cit., 292), however, only one pot, of BII:b type, has been mentioned as located in this grave. Also, when we reviewed the find assemblage a few years ago, Valter Lang (pers. comm.) confirmed the presence of only one vessel among the sherds previously ascribed to two pots (AI 4620: 8); according to an updated typology (see Lang 2007, $127 \mathrm{ff}$; 2018, $131 \mathrm{ff}$.), it is a pot of Ilmandu style with striated surface. ${ }^{5}$ Although the BII:b type and the Ilmandu style are not necessarily incompatible, the situation raises an array of questions about the location, number, decoration, and type of clay vessels in this grave. Moreover, a similar discrepancy is observable in the case of grave 1 at Iru (Lõugas 1976, 48; Lang 1992, 25; 1996, 120-121). As a particularly unfortunate aspect, it remains unknown whether or not the obtained radiocarbon date could have been applied to date pottery in cists. Although part of the problem is poor excavation records, the case also suggests caution in regard to the prevalent pottery typologies and implies the need for a more consistent study. Also, small but inconvenient discrepancies like those discussed in this sub-chapter should be addressed instead of 'sliding over' as if they do not exist.

\footnotetext{
${ }_{5}$ Lang has basically two pottery typologies: one is based on the shape of the vessels (e.g. Lang 1996) and the other considers also other parameters such as decoration, surface finish, and fabric type (e.g. Lang 2007; 2018). The two typologies are partly congruent; unfortunately, the extent and details of the congruence have not been discussed in the literature, which renders the use of the typologies difficult. For instance, while the BII:b vessels in the cists generally translate into Lüganuse-style vessels in terms of the later typology, the BII:b vessels outside the cists belong to more than one 'style' with possibly different chronologies (V. Lang, pers. comm.). In the case of Pärna 1, this means that in Lang 1996 the pottery of this grave is equalled to the most characteristic pottery type found in the cists; according to the new determination, however, this no longer applies, since Ilmandu-style pots have not been found in the cists and they may therefore be slightly later in date (see Lang 2007, $130 \mathrm{ff}$; 2018, 133-134). Skipping a detailed review of the inferences that follow such modifications, an overall conclusion is that such pottery cannot be used for establishing the age of a stone-cist grave.
} 


\section{Proosa, Lagedi, and Saha}

The stone-cist graves at Proosa, Lagedi, and Saha have not been radiocarbon dated, and because of poor artefact provisions, they were not of crucial importance in Lang's chronological analysis (1996). These groups are therefore dealt with briefly in one sub-chapter. Of the five stone-cist graves in the land of Proosa farm, only one badly damaged grave next to the richly furnished Iron Age stone settings has been excavated in 1979 (Deemant 1980). The cist contained a fragment of a bone item, allegedly a bridle bit, which has been dated to the end of the Bronze Age or the beginning of the Iron Age (Lang 1996, 177, 293). The graves at Saha and Lagedi were excavated between 1903 and 1910 (Spreckelsen 1907; 1927), probably with no bones collected for storage. At Lagedi, a dozen stone-cist graves were scattered along with several stone graves of later dates across an area of ca $0.4 \mathrm{~km}^{2}$. Relying on a fragmented bone pin, two clay vessels, and a bronze mount, all typologically indefinite, and considering the size of the cemetery, Lang (1996, 293, 589) dated the stone-cist graves to ca 600-200 BC. Pähklimägi at Saha had at least two stone-cist graves combined with perhaps two Roman Iron Age tarand graves. One of the cists contained probably two unidentifiable bone objects. Lang (1996, 240-241, 246; cf. op. cit., 293) dated part of the site's pottery to the Early PreRoman Iron Age and another part, together with a bone harpoon and a few stone items, to the Late Bronze Age. He believes that the Bronze Age finds originated from a (hypothetical) settlement site that pre-dated the stone-cist graves, established in the Early Pre-Roman period. However, in view of the absence of a defined settlement layer and the ambiguity of the artefacts' dates, the interpretation remains debatable. There are 3-5 other, unexcavated grave groups at Saha that are probably stone-cist cemeteries (ibidem, 248-249).

\section{Discussion}

\section{Results and representativeness}

It is clear from the above that establishing quantitative figures of cemetery, grave, and burial numbers is difficult; any such exact figure can only be conditional. Bearing this in mind, it can be resumed that the area under discussion contained approximately a dozen stone-cist cemeteries with altogether 70-75 cairns that had survived until excavation or registration. Excavations have been conducted at almost 50 cairns at eight cemeteries (if Jaani and Pärna at Väo were separate groups and Iru a single group). Radiocarbon dates are available for nine cairns in five cemeteries (Fig. 6). In two of the groups (Kangru and Pärna), merely single individuals have been radiocarbon analysed; two groups (Iru and Kuristiku) include each a single thoroughly analysed grave with 4-5 radiocarbon-dated individuals; and the most extensively analysed, with 15 radiocarbon determinations, are the Jaani graves (or triple grave). The overall number of radiocarbon dates is 28 , each date probably 


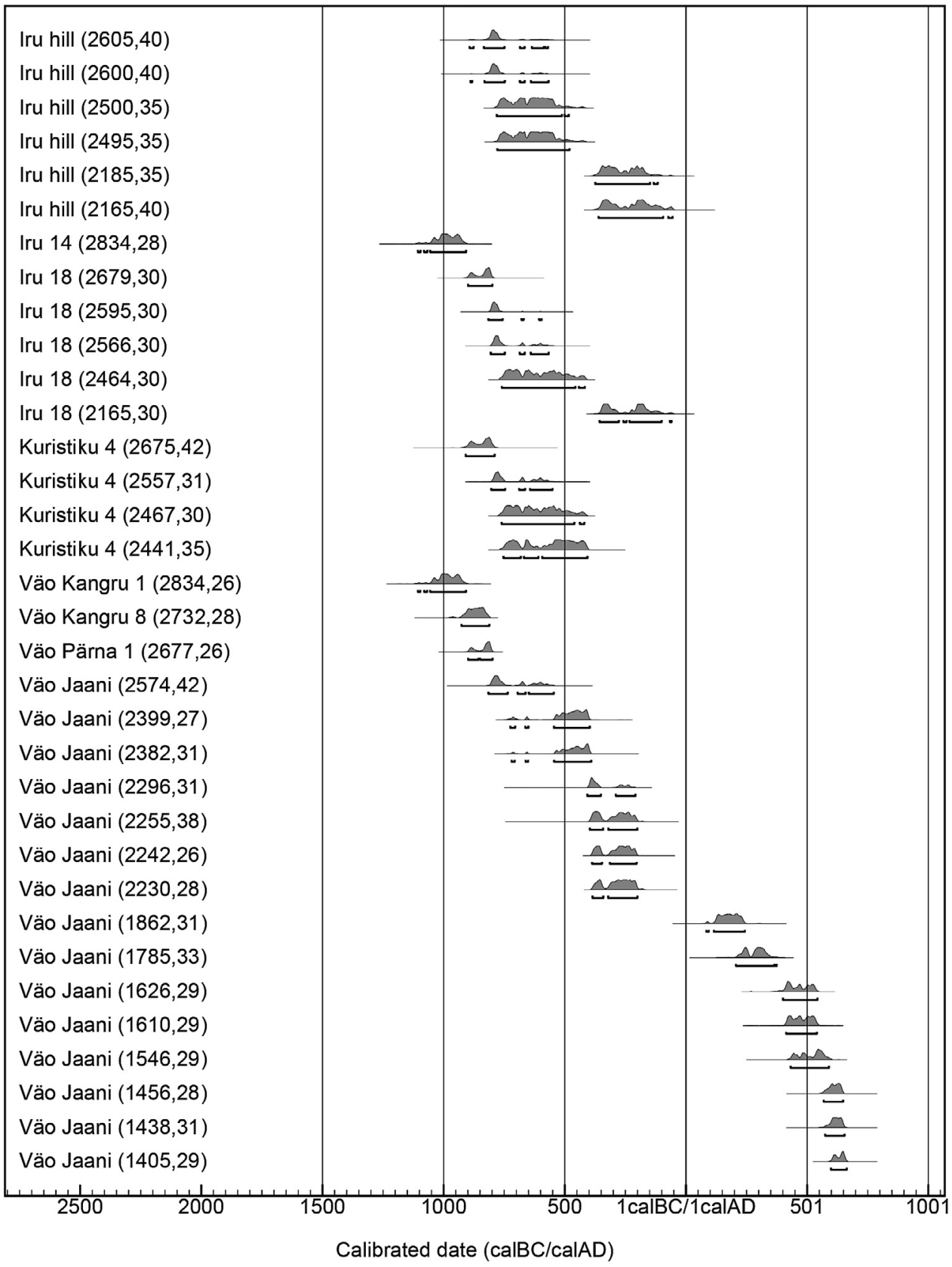

Fig. 6. Radiocarbon dates from the stone-cist graves (bones, AMS) and the hilltop site (charcoal, conventional) in the area around the lower reaches of the Pirita River, corrected to calendar ages by OxCal v4.4.2 with the IntCal20 calibration curve (Bronk Ramsey 2009; Reimer et al. 2020). The figure shows $95.4 \%$ probability ranges. Data from Lang 1996, Laneman et al. 2015, Saag et al. 2019, and this study. In the case of the hilltop site at Iru, only data concerning the Bronze and Pre-Roman Iron Age settlement phases is included. 
standing for a separate individual. Proceeding from Heapost's data, Lang (1996, 354 ) estimated the number of individuals in a single mound to have been generally 4-5, which amounts to a minimum figure of ca 300 people for the known graves in the area. Heapost's estimations, however, are probably too modest (Laneman et al. 2015; see also above). In any case, the inferences drawn from the less than 30 radiocarbon-dated individuals can only be of a limited extent. In addition to the quantitative limitations, the scope of inferences is reduced by the poor quality of excavation and osteological records.

The results suggest that the cemeteries of Iru and Kangru were probably present by ca 900 BC and those of Kuristiku and Pärna by ca $800 \mathrm{BC}$ at the latest, and the Jaani stone-cist graves were probably established between 800 and $550 \mathrm{BC}$ at the latest. The latest possible date for the cist burials is around $400 \mathrm{BC}$, although in those cases long stretches of time are drawn across the Hallstatt plateau of the calibration curve. This means that the true date of such burials can be considerably earlier than $400 \mathrm{BC}$. Unfortunately, in the absence of well-datable artefacts and closed find complexes such extended dates are impossible to narrow down. A general date of stone-cist graves between 1100 and $400 \mathrm{BC}$ is consistent with radiocarbon data from elsewhere, although there are a few groups that may have included even slightly older graves (Laneman \& Lang 2013; Laneman 2021a). The results from Iru and Jaani at Väo show that the cairns (though probably not the cists) contained human remains also from later centuries of the Iron Age, which is also a phenomenon observed in other regions (Laneman 2012; 2021b). In the case of the Pre-Roman Iron Age burials that immediately post-date $400 \mathrm{BC}$, the plateau effect is at work again, making it impossible to determine whether such burials indicate continuous burial since the Bronze Age or a chronologically separate episode in the cemetery use.

\section{Discrepancies between new and old dates}

The so far relevant chronology (Lang 1996) places the emergence of all cemeteries in the area, except for Kangru at Väo, to approximately 600 or 500 BC. Admittedly, the assumption that the inventory-less graves are not among the earliest may have distorted the proposed dates, although for no more than a maximum of 50-100 years (op. cit., 293). In most cases, the dates in this study are at least 300 years later than the estimations based on radiocarbon. This necessitates an analysis as to why the radiocarbon dates differ from the previous dates based on artefact typo-chronologies - the more so because radiocarbon dating is, ideally, a method to only complement, not replace, other methods of age determination (e.g. Mook \& Waterbolk 1985, 1-2; Punning 2005).

In the case of the radiocarbon dates, it has to be noted that the freshwater reservoir effect is not entirely ruled out. Considering the many factors that affect the isotope data (Schulting 1998; Montgomery et al. 2009; Keaveney \& Reimer 2012; O’Connell et al. 2012; Salazar-García et al. 2014; Eerkens et al. 2017), there is currently no good reason to assume that the quality control measurements are 
outside acceptable limits; on the other hand, only a further study could possibly confirm or refute that (see e.g. Philippsen 2013). An indication of reliability is the fact that the results are well comparable to similar data from other sites, including those where well-datable artefacts allow assessing the accuracy of the radiocarbon determinations. In the discussed region, the razor from Kangru 4 at Väo is a relatively good match for the radiocarbon dates of the site.

As for the dates based on artefact typo-chronologies, they also have unavoidable weaknesses, which possibly contribute to the disagreement with the radiocarbon data. Before proceeding with the details, it has to be emphasised once again that stone-cist graves are poor in artefacts and contain no closed find complexes. The cists and sometimes the adjacent areas were used for burial repeatedly, and as aboveground structures, the cairns have been open to various disturbances during the millennia of their existence. Therefore, their chronology has always been a headache for researchers (historiography is a topic in its own right and beyond the scope of this study, but see e.g. Laneman \& Lang 2013, 94-95).

Things have been more favourable where bronze items of Nordic origin have been present. The dates ascribed to those few grave groups have turned out to be in better agreement with radiocarbon data. In the Pirita area, this tendency is observable in the case of the Kangru group. In most cases, however, the finds in stone-cist graves have no counterparts in closed find complexes. The most frequent of such finds are, in the Pirita area as well as elsewhere, bone pins and pottery. In Lang's study, the cornerstone of dating such graves is a type of coarse-grained clay vessels, denominated as BII:b (Lang 1996, 43-46). Accordingly, this type of pottery was relatively frequent in stone-cist graves, but scarce in Late Bronze Age fortified settlements, including that at Iru. It followed that the pottery was generally later in date than the fortified settlements, i.e. predominantly a post-500 BC occurrence (Lang 1992, 25; 1996, 285). Combined with the deep-rooted belief in academia that stone-cist graves were first and foremost a Pre-Roman Iron Age phenomenon, the conclusion made perfect sense at the time. After the pottery were dated the bone pins with widening heads that had generally larger dimensions than similar bone pins in those stone-cist graves that contained bronze items of Nordic Bronze Age Periods IV or V (ibidem). Lang calls such finds variant 3 of the spade-headed bone pins, whereas the smaller and allegedly earlier pins belonged to variants 1 and 2 (1992; 1996, 121).

One of the weak spots of these dating conventions is the circular argumentation that has been applied in some cases: the pins that had been dated based on the pottery were used for dating the pottery (Lang 1996, 43, 46). Additionally, it is conceivable that the absence of a pottery type from settlements and presence in mortuary contexts has reasons other than chronological; and moreover, the dates of the fortified settlements within the Late Bronze Age are ambiguous (see below). Today there are also more direct indications that the discussed pottery type is possibly older than previously thought. Radiocarbon dating of charred organics on a few vessels resulted in the calibrated dates of ca 11th-9th centuries BC (Kriiska 
et al. 2005; Lang 2007, 130), although it has to be noted that the vessels came from settlement sites, and that in the absence of published isotope data the reliability of the results can be questioned. In stone-cist graves, individuals that were possibly buried with this type of pots have been radiocarbon dated only in the cists at Rebala, with the results spanning the Hallstatt plateau at 800-500/400 BC (Laneman 2021b), whereas the potentially similar case of Pärna 1 at Väo turned out to be unreliable (see above). A pot of BII:b type has also been reported from radiocarbon-dated Kangru 8 at Väo, but this specimen was located outside the cists. This case brings us to another matter that could have easily affected the accuracy of the achieved dates in Lang 1996: using such pottery for dating the burials in the cists. The pottery outside cists is usually highly fragmented, so that the vessels can rarely be reconstructed and assigned to a type; moreover, there is no certainty how the vessels related to the burials. This means that dating on the basis of such material is generally an unreliable method. Furthermore, today it is clear (although not clearly announced in the literature) that the BII:b type, particularly the vessels outside cists, includes stylistically different specimens, and the differences may also have chronological relevance (V. Lang, pers. comm.). This implies that the dates of the stone-cist graves in Lang 1996 that base on the BII:b pottery outside the cists are no longer trustworthy.

If the age of the BII:b pottery has been underestimated, then the same applies to the bone pins that have been dated according to the pottery. This has also been acknowledged in Lang's later studies $(2007,162)$, although without broader discussion on the implications. As for the relative chronology of the bone pins (Lang 1992), the radiocarbon data collected over the past decade is inconclusive in regard to the chronological differences of the three variants of the spade-headed pins. The possibly applicable radiocarbon determinations are few and the number of the pins is small (23), which means that even a single nonconformity casts a shadow on the inferences drawn from such a small population. To provide an example, the spadeheaded pins from Asva belong to variant 1 and should therefore be among the earliest specimens; however, there is no evidence that the site is earlier in date than the stone-cist graves that contain variant 3 pins (Sperling 2014, 307 ff.; Sperling et al. 2020, 59). Another weakness of the referred typology is that, while meticulously comparing the dimensions of the pins' heads, the underlying assumption appears to be that the pins were a product of a highly specialised craft. However, the pins are simple in design, and it is conceivable that their different dimensions resulted from local preferences and traditions, not chronological differences. Besides, there are bone pins that have an upper part designed differently than a 'spade', which shows that there was room for creativity and uniqueness.

As for the few metal items at Iru and Jaani, Väo, which have been additional arguments in favour of a date in or close to the Pre-Roman Iron Age (see above), it has to be noted that all these graves, including the cists, were severely damaged. It means that there is no certainty that the artefacts in question date the cist burials, i.e. the establishment of the graves; also, their typo-chronological dates are stretched 
and imprecise. And finally, when assessing the reasoning in Lang 1996, it is probably worth remembering that this study proceeded from a situation where the stone-cist graves of the area had mainly been dated to ca 250-1 BC. The web of previous knowledge should not be underestimated. In other words, it may have played a role in dating the majority of the stone-cist graves in the Pre-Roman Iron Age, though in its earlier half. It is possible that the same phenomenon holds me back from confident declaration that all stone-cist graves have been established within the Bronze Age.

It has to be added that the discussed dates in Lang 1996 are essentially the time ranges within which the groups of graves were used for burial. These estimates are based on the number of graves in a group and an assumption that the growth of a cemetery was one mound per generation (Lang \& Ligi 1991; Lang 1996, 291-292; 2007, 223-224). Unfortunately, radiocarbon dating is not sufficiently precise a method to test this theory, not even in more thoroughly sampled grave groups (Laneman 2021a; 2021b). However, it is interesting to speculate that if Lang is right about the rate of the cemetery growth and the obtained radiocarbon data is reliable, then all cemeteries in the area may have been abandoned by $500 \mathrm{BC}$ at the latest, and some already earlier. Also, the duration of cemetery use, along with the number of buried individuals, have been crucial figures to develop the theory that burial in a stone-cist grave was available only for selected members of the community (Lang \& Ligi 1991; Lang 1996, 354-355; 2007, 224). Although the osteological analysis of the Jaani graves (Laneman et al. 2015) and observations during sampling showed that the number of buried individuals is larger than previously thought, this is far too little to contribute to the theory of selective burial. For more accurate figures, proper osteological analyses according to modern standards are necessary. Moreover, part of the buried possibly date from other periods than the stone-cist era, and this can be ascertained only by radiocarbon dating.

\section{Further implications}

Shifts in the stone-cist graves' chronology affect the way the relationship between the graves and the fortified settlement on the hilltop at Iru is viewed. 'Fortified settlement', however, is a generic term; the particular settlement had probably no artificial defences. Excavations on the hill have uncovered remains of dwelling houses and residues of bronze casting, and a contemporaneous settlement site has been located at the foot of the hill. Lang (1996, $462 \mathrm{ff}$.; 2007, 70-71, 94) views the site as the residence of a local chief and his retinue who controlled bronze circulation and other handicrafts and trade. According to him, the settlement on the hilltop was established at ca $800 \mathrm{BC}$ and, as part of the pan-European bronze trade network, was abandoned when the network collapsed at ca 500 BC. Around the latter date, other settlement units, probably single farms, established their stone-cist cemeteries. The society became seemingly more egalitarian, although Lang believed that the greater variety of finds in the stone-cist graves at Iru indicated a household 
more powerful than the others. ${ }^{6}$ In Lang's terminology, the system of a central settlement and single farms had been replaced by the system of one dominating farm.

The first thing to note about this scenario is that the date of the 'central settlement', 800-500 BC, is provisional. The find assemblage of the site is rather nondescript, with mainly poorly datable pottery and bone items, and only few metal objects attributable to Period V as well as Period VI of the Nordic Bronze Age (Lang 1996, 40-50). The four associated radiocarbon dates range from ca 900 to $480 \mathrm{BC}$, in large part coinciding with the unfortunate plateau of the calibration curve (op. cit., 51; Fig. 6). The radiocarbon-analysed charcoal came from charred timbers, which in at least one case (the first entry in Fig. 6) had been part of a dwelling (Lang 1987; 1988). The further details of the samples are unknown, which means that the old wood effect cannot be ruled out (Mook \& Waterbolk 1985, 49; Warner 1990, 162). Comparison with the few analogous settlements in coastal Estonia is unhelpful, because the dating of these sites faces similar difficulties (e.g. Lang 1996, 306; Sperling 2014, 307 ff.; Sperling et al. 2020, 59). Lang also admits that the date of $800-500 \mathrm{BC}$ is only a 'convention' $(1996,51)$, although in other places there is a tendency to present it as firm and unconditional (e.g. Lang 1996, 462; 2018, 159; 2020, 172). However, a methodologically strict approach requires acknowledging that the true, or more precise, date of the settlement within the indicated period of almost half a millennium remains unknown. In other words, it would be incorrect to adopt a fixed view that the settlement was established at 800 (or 900) BC and abandoned at $500 \mathrm{BC}$.

Turning to the graves, the radiocarbon data suggest that the majority of cemeteries had probably been established before the settlement on the hill, or at approximately the same time. At the other end of the timescale, the terminal point of burial is unknown: the dates of the probably youngest relevant interments stretch along the Hallstatt plateau until ca 400 BC. As mentioned above, if the radiocarbon data is reliable and if Lang is right in his estimations on the cemeteries' duration, burial must have been stopped between 600 and $500 \mathrm{BC}$ at the latest. It is not unlikely that the settlement site and the cemeteries were abandoned at approximately the same time.

In conclusion, the overall impression created by the recently added radiocarbon dates is that the developments concerning the central settlement and the graves (i.e. other settlement units) may have been more synchronous than previously thought. Theoretically, it is well conceivable that such a settlement is established in a region that already is densely populated and that the collapse of a power centre has a greater effect than the society becoming more egalitarian. Admittedly, however, the archaeological evidence in all its chronological and other ambiguities can easily be bent to fit almost any theory, which is the reason I prefer refraining from painting a more detailed picture of the situations and processes. For the same reason I will

${ }^{6}$ It is relevant to note here that the relation of those who had lived up on the hill and those who buried their dead in the stone-cist graves at Iru has remained unclear. The distance between the grave field and the hill was, very roughly, a kilometre (Lang 1996, 118). 
not introduce the currently topical issues of ethnicity and migration to the theme: there is always a way to make the archaeological information concurring with for instance the theory that the fortified settlement and the stone-cist graves had different ethnic backgrounds (Lang 2018). The mentioned subjects need considerably more space than available here to differentiate between facts and speculation.

The centuries that followed the stone-cist grave era were, in the discussed area, poor in monuments and other finds until the emergence of tarand graves in the 3rd4th centuries AD (Lang 1996, 332, 383). The obtained radiocarbon data has little to add here. Lang placed the beginning of the 'poor' period at $200 \mathrm{BC}$; the new data shifts the date a few centuries back in time, to $400 \mathrm{BC}$ at the latest. It is known that the hill at Iru was settled again in the Pre-Roman Iron Age, although the nature of the short-lived settlement is unclear. A charred timber from the thin cultural layer, which contained predominantly pottery, has been radiocarbon dated to ca 380-50 BC (Lang 1996, 51; Fig. 6). Interestingly, a skeleton in Iru 18 and several of them in Jaani graves at Väo yielded similar dates. Differently from the hill where the PreRoman Iron Age horizon was stratigraphically separated from the Bronze Age strata, in the case of the graves it is difficult to determine whether the skeletons in question were the very last interments of the continuous burial that began in the Bronze Age or manifest a new stage in the graves' lifecycle. Similar Pre-Roman Iron Age burials may have been present in other stone-cist cemeteries of the area. Shepherd's crook pins, which are very characteristic of the Pre-Roman period, were present in the graves of Kangru, Proosa, and Lagedi (Lõugas 1981, 391; Deemant 1980; Spreckelsen 1927, 30, 32; see also Howen 1900, 95). However, this is not necessarily an indication of burial, and the same applies to the occasional finds of later dates, such as the 4th-5th-century bracelets in Kuristiku 4 (see above) or a 5th-6th-century buckle in Kangru 4 at Väo (Lõugas 1981, 391; Lang 1996, 140). On the other hand, the late finds in Jaani graves at Väo were true indications of burial, although in this case, the quantity of both the finds and bones were beyond 'occasional'. The difficulties in contextualising these burials have been described in another paper (Laneman et al. 2015).

\section{Conclusion}

The area around the lower reaches of the Pirita River is unique in Estonia: there is no other microregion with a comparable number of excavated stone-cist cemeteries. Despite this abundance, the respective bone assemblages have so far escaped systematic radiocarbon dating for reasons that include the absence or inaccessibility of bones, unreliable contexts of damaged graves, and contradictions between the superficial excavation and osteological records. The 28 radiocarbon dates that are currently available for the almost 50 excavated stone-cist graves, each grave a resting place for several people, allow drawing inferences of only very 
limited scope. The data suggest that stone-cist graves emerged in the area between 1100 and $900 \mathrm{BC}$ at the latest and the last of them were built around $400 \mathrm{BC}$ at the latest. The shift in the graves' chronology implies that their synchrony with the socalled fortified settlement at Iru is probably greater than previously thought. At Väo (Jaani) and perhaps Iru, radiocarbon has detected burials that epitomise the re-use of old graves centuries after their construction.

The results are, in broad terms, consistent with comparable data from other regions of Estonia. However, the radiocarbon dates are generally earlier than the previous typo-chronological study of the artefact finds had suggested. The discrepancy is not particularly surprising, given the scarcity of artefact finds and lack of closed find complexes, which make building reliable and reasonably precise artefact chronologies extremely difficult. On the other hand, as long as a special study has not ruled the freshwater reservoir effect out, it is wise to stay conservative and cautious with interpretations.

Further radiocarbon analyses would potentially bring deeper insights not only into the chronology but also into the burial practices and thus nature of these mortuary monuments. The amount of excavated grave groups means opportunities for chronological comparison of the groups. However, it is wise to keep the expectations curbed, because the flatness of the Hallstatt plateau very likely continues to be a stumbling block. Also, radiocarbon studies in the future should be preceded by standard osteological analyses. But even then, as far as the sites discussed in this paper are concerned, the scope of potential inferences is likely to remain limited because of inadequate excavation records.

\section{Acknowledgements}

Samples for radiocarbon dating from Iru 18 and Kuristiku 4 were collected in cooperation with Martin Malve. I am also grateful to Leiu Heapost for the information concerning the skeletons of Iru 18; to Flemming Kaul and Karen Margrethe Hornstrup for discussing the bronze razor of Väo; to Valter Lang for his comments on the paper; to Kristi Tasuja for assistance with the research collections; and to Kristel Roog for preparing the illustrations for print. The publication costs of this article were covered by the Estonian Academy of Sciences, the Institute of History and Archaeology at the University of Tartu, and the Archaeological Research Collection of Tallinn University.

\section{References}

Baudou, E. 1960. Die regionale und chronologische Einteilung der jüngeren Bronzezeit im Nordischen Kreis. (Acta Universitatis Stockholmiensis. Studies in North-European Archaeology, 1.) Almqvist \& Wiksell, Stockholm.

Bronk Ramsey, C. 2009. Bayesian analysis of radiocarbon dates. - Radiocarbon, 51: 1, 337-360.

Deemant, K. 1980. Ausgrabungen des Steinkistengrabes von Proosa. - TATÜ, 29: 4, 360-361. 
Eerkens, J.W., Washburn, E. \& Greenwald, A. M. 2017. Weaning and early childhood diets at two Early Period sites: implications for parental investment and population growth in Central California. - California Archaeology, 9: 2, 199-222.

Hornstrup, K. M., Olsen, J., Heinemeier, J., Thrane, H. \& Bennike, P. 2012. A new absolute Danish Bronze Age chronology as based on radiocarbon dating of cremated bone samples from burials. - Acta Archaeologica, 83, 9-53.

Howen, A. 1900. Ausgrabungen in Estland. - Beiträge zur Kunde Est-, Liv- und Kurlands, V, 92-96. Jaanits, K. \& Lavi, A. 1978. Über die Ausgrabungen eines Steinkistengrabes in Väo. - TATÜ, 27: 4, 330-333.

Jaanits, L., Laul, S., Lõugas, V. \& Tõnisson, E. 1982. Eesti esiajalugu. ENSV Teaduste Akadeemia Ajaloo Instituut, Eesti Raamat, Tallinn.

Kaul, F. 1998. Ships on Bronzes: Study in Bronze Age Religion and Iconography. (Publications from the National Museum. Studies in Archaeology \& History, 3: 1-2). National Museum, Copenhagen.

Kaul, F. 2018a. The Nordic razor as a medium of creativity. - Considering Creativity: Creativity, Knowledge and Practice in Bronze Age Europe. Ed. J. Sofaer. Archaeopress Archaeology, Oxford, $105-115$.

Kaul, F. 2018b. The one-edged razor: a vivid medium of creativity and meaning. - Creativity in the Bronze Age: Understanding Innovation in Pottery, Textile, and Metalwork Production. Eds L. Bender Jørgensen, J. Sofaer \& M. L. S. Sørensen. Cambridge University Press, 161-176.

Keaveney, E. M. \& Reimer, P. J. 2012. Understanding the variability in freshwater reservoir offsets: a cautionary tale. - Journal of Archaeological Science, 39, 1306-1316.

Kriiska, A., Lavento, M. \& Peets, J. 2005. New AMS-dates of the Neolithic and Bronze Age ceramics in Estonia. - EJA, 9: 1, 3-31.

Laneman, M. 2012. Stone-cist grave at Kaseküla, western Estonia, in the light of AMS dates of the human bones. - EJA, 16: 2, 91-117.

Laneman, M. 2021a. The date of the stone-cist cemetery at Jõelähtme reconsidered. - EJA, 25: 1, 55-89.

Laneman, M. 2021b. Chronology of a group of stone-cist graves in northern Estonia: radiocarbon dates from Lastekangrud at Rebala. - EJA, 25: 2, 113-139.

Laneman, M. \& Lang, V. 2013. New radiocarbon dates for two stone-cist graves at Muuksi, northern Estonia. - EJA, 17: 2, 89-122.

Laneman, M., Lang, V., Malve, M. \& Rannamäe, E. 2015. New data on Jaani stone graves at Väo, northern Estonia. - EJA, 19: 2, 110-137.

Lang, V. 1983. Ein neues Steinschiffsgrab in Nordestland. - TATÜ, 32: 4, 293-295.

Lang, V. 1987. Über die Konstruktion des Mittelwalls auf dem Burgberg Iru. - TATÜ, 36: 4, 358 365 .

Lang, V. 1988. Aruanne arheoloogilistest kaevamistest Iru linnuse keskvallil 1985. ja 1986. a. (Manuscript in the archive of the Archaeological Research Collection of Tallinn University.)

Lang, V. 1992. Eesti labidaspeaga luunõelte dateerimisest. - Stilus, 1. Eesti Arheoloogiaseltsi teated, 8-32.

Lang, V. 1996. Muistne Rävala: muistised, kronoloogia ja maaviljelusliku asustuse kujunemine LoodeEestis, eriti Pirita jõe alamjooksu piirkonnas, I-II. (MT, 4. Töid arheoloogia alalt, 4.) Eesti Teaduste Akadeemia Ajaloo Instituut, Tallinn.

Lang, V. 2007. The Bronze and Early Iron Ages in Estonia. (Estonian Archaeology, 3.) Tartu University Press.

Lang, V. 2018. Läänemeresoome tulemised. (MT, 28.) Tartu Ülikooli Kirjastus.

Lang, V. 2020. Pronksiaeg ja eelrooma rauaaeg (1750 eKr - $50 \mathrm{pKr})$. - Eesti ajalugu, I: Eesti esiaeg. Toim V. Lang. Tartu ülikooli ajaloo ja arheoloogia instituut, Tartu, 155-230.

Lang, V. \& Ligi, P. 1991. Muistsed kalmed ajaloolise demograafia allikana. - Arheoloogiline kogumik. Toim L. Jaanits \& V. Lang. (MT, 1.) Eesti Arheoloogiaselts jt, Tallinn, 216-238.

Lõugas, V. 1970. Eesti varane metalliaeg (II a.-tuh. keskpaigast e.m.a - 1. sajandini m.a.j): dissertatsioon ajalooteaduste kandidaadi kraadi taotlemiseks. Eesti NSV TA Ajaloo Instituut. (Manuscript in the archive of the Archaeological Research Collection of Tallinn University.) 
Lõugas, V. 1975. Ausgrabungen der Steinkistengräber in Väo. - TATÜ, 24: 1, 77-78.

Lõugas, V. 1976. Ausgrabungen der Steingräber und Flurrelikte in Iru. - TATÜ, 25: 1, 48-52.

Lõugas, V. 1981. Archäologische Rettungsgrabungen im neuen Wohngebiet Lasnamäe in Tallinn. TATÜ, 30: 4, 390-393.

Minami, M., Mukumoto, H., Wakaki, S. \& Nakamura, T. 2019. Effect of crystallinity of apatite in cremated bone on carbon exchanges during burial and reliability of radiocarbon dating. - Radiocarbon, 61: 6, 1823-1834.

Montgomery, J., Möldner, G., Cook, G., Gledhill, A. \& Ellam, R. 2009. Isotope analysis of bone collagen and tooth enamel. - 'Clothing the Soul Divine'. Burials at the tomb of St Ninian: Excavations at Withorn Priory 1957-67. (Archaeology Report, 3.) Ed. C. Lowe. Edinburgh: Historic Scotland, 65-82. Mook, W. G. \& Waterbolk, H. T. 1985. Radiocarbon dating. (Handbooks for Archaeologists, 3.) European Science Foundation, Strasbourg.

O'Connell, T. C., Kneale, C. J., Tasevska, N. \& Kuhnle, G. G. C. 2012. The diet-body offset in human nitrogen isotopic values: a controlled dietary study. - American Journal of Physical Anthropology, 149: 3, 426-434.

Olsen, J., Hornstrup, K. M., Heinemeier, J., Bennike, P. \& Thrane, H. 2011. Chronology of the Danish Bronze Age based on ${ }^{14} \mathrm{C}$ dating of cremated bone remains. - Radiocarbon, 53: 2, 261-275.

Philippsen, B. 2013. The freshwater reservoir effect in radiocarbon dating. - Heritage Science, 24: 1. https://doi.org/10.1186/2050-7445-1-24

Punning, M. 2005. Kuidas hinnata radiosüsiniku meetodit tänapäeval? - Eesti Loodus, 11, 18-22. http://vana.loodusajakiri.ee/eesti_loodus/artikkel1288_1279.html

Reimer, P. J., Austin, W. E. N., Bard, E., Bayliss, A., Blackwell, P. G., Bronk Ramsey, C., Butzin, M., Cheng, H., Edwards, R. L., Friedrich, M., Grootes, P. M., Guilderson, T. P., Hajdas, I., Heaton, T. J., Hogg, A. G., Hughen, K. A., Kromer, B., Manning, S. W., Muscheler, R., Palmer, J. G., Pearson, C., van der Plicht, J., Reimer, R. W., Richards, D. A., Scott, E. M., Southon, J. R., Turney, C. S. M., Wacker, L., Adolphi, F., Büntgen, U., Capano, M., Fahrni, S. M., Fogtmann-Schulz, A., Friedrich, R., Köhler, P., Kudsk, S., Miyake, F., Olsen, J., Reinig, F., Sakamoto, M., Sookdeo, A. \& Talamo, S. 2020. The IntCal20 Northern Hemisphere radiocarbon age calibration curve (0-55 cal kBP). - Radiocarbon, 62: 4, 725-757.

Saag, L., Laneman, M., Varul, L., Malve, M., Valk, H., Razzak, M. A., Shirobokov, I. G., Khartanovich, V. I., Mikhaylova, E. R., Kushniarevich, A., Scheib, C. L., Solnik, A., Reisberg, T., Parik, J., Saag, L., Metspalu, E., Rootsi, S., Montinaro, F., Remm, M., Mägi, R., D’Atanasio, E., Ryunosuke Crema, E., Diez-del-Molini, D., Thomas, M. G., Kriiska, A., Kivisild, T., Villems, R., Lang, V., Metspalu, M. \& Tambets, K. 2019. The arrival of Siberian ancestry connecting the Eastern Baltic to Uralic speakers further east. - Current Biology, 29: 10, 1701-1711.

Salazar- García, D. C., Richards, M. P., Nehlich, O. \& Henry, A. G. 2014. Dental calculus is not equivalent to bone collagen for isotope analysis: a comparison between carbon and nitrogen stable isotope analysis of bulk dental and dentine collagen from same individuals from the Medieval site of El Raval (Alicante, Spain). - Journal of Archaeological Science, 47, 70-77.

Schulting, R. J. 1998. Slighting the sea: stable isotope evidence for the transition to farming in northwestern Europe. - Documenta Praehistorica, XXV, 203-218.

Snoeck, C., Brock, F. \& Schulting, R. J. 2014. Carbon exchange between bone apatite and fuel during cremation: impact on radiocarbon dates. - Radiocarbon, 56: 2, 591-602.

Sørensen, M. L. S \& Appleby, G. 2018. To decorate a Nordic Bronze Age razor: a design challenge. - Creativity in the Bronze Age: Understanding Innovation in Pottery, Textile, and Metalwork Production. Eds L. Bender Jørgensen, J. Sofaer \& M. L. S. Sørensen. Cambridge University Press, 191-205.

Sperling, U. 2014. Aspekte des Wandels in der Bronzezeit im Ostbaltikum: die Siedlungen der AsvaGruppe in Estland. (EJA. Supplementary Volume, 18/2S.) Tallinn.

Sperling, U., Karlsen, H.-J., Lang, V., Kimber, A., Lõugas, L. \& Lau, R. 2020. Ausgrabungen in der Bronzezeitsiedlung von Asva im Jahr 2019. - AVE, 2019, 51-60.

Spreckelsen, A. 1907. Ausgrabungen in Saage, Kirchsp. Jeglecht, Estland. - Beiträge zur Kunde Est-, Liv- und Kurlands, VI, 376-419. 
Spreckelsen, A. 1927. Das Gräberfeld Laakt (Lagedi), Kirchspiel St. Jürgens, Harrien, Estland. (Õpetatud Eesti Seltsi toimetused / Verhandlungen der Gelehrten Estn. Gesellsch., 24.) Dorpat.

Tõnisson, E. \& Selirand, J. 1964. Nõukogude Eesti arheoloogide välitööd aastail 1958-1962. TATÜ, 13: 3, 225-246.

Van Strydonck, M. 2016. Radiocarbon dating of cremated bones: an overview. - Isotopic Landscapes of Bioarchaeology: Proceedings of the International Workshop 'A Critical Look at the Concept of Isotopic Landscapes and its Application in Future Bioarchaeological Research', Munich, October 1315, 2014. Eds G. Grupe \& G. C. McGlynn. Springer, 69-89.

Van Strydonck, M., Boudin, M. \& De Mulder, G. 2009. ${ }^{14} \mathrm{C}$ dating of cremated bones: the issue of sample contamination. - Radiocarbon, 51: 2, 553-568.

Vassar, A. 1936. Kivikalme Nehatus. - Eesti Rahvuslaste Klubid, 7/8, 190-195.

Vassar, A. 1959. Väo kivikirstkalme kaevamine 3.-28. juulil 1959. (Manuscript in the archive of the Archaeological Research Collection of Tallinn University.)

Vassar, A. 1966. Loode-Eesti hõimudest meie ajaarvamise I aastatuhande algupoolel. - TATÜ, 15: 2 , 190-203.

Warner, R. B. 1990. A proposed adjustment for the 'old-wood effect'. - Proceedings of the Second International Symposium ${ }^{14} \mathrm{C}$ and Archaeology, Groningen 1987. Eds W. G. Mook \& H. T. Waterbolk. (PACT, 29.) Council of Europe, Parliamentary Assembly, Strasbourg, 159-172.

\section{Margot Laneman}

\section{PIRITA JÕE ALAMJOOKSU KIVIKIRSTKALMETE RADIOSÜSINIKUDATEERINGUD}

\section{Resümee}

Pirita jõe alamjooksu ümbrus Tallinna külje all on üks arheoloogiliselt kõige paremini uuritud piirkondi Eestis. Seejuures on eriti märkimisväärne, et enamik Eesti täielikult või suuremas osas läbi kaevatud kivikirstkalmete rühmi paiknes just selles piirkonnas. Teatud mööndustega - kalmerühmi ja isegi kalmeid on mõnikord keeruline eristada - võib öelda, et siit on teada 70-75 tosinkonna rühma vahel jagunevat kivikirstkalmet, millest seitsme või kaheksa rühma umbes pooltsadat kalmet on kaevatud, ehkki erinevas ulatuses ja kõikuva kvaliteediga. Piirkonna muistiseid ja asustuslugu on üksikasjalikult analüüsinud Valter Lang, kes 1990. aastatel suuresti just selle materjali põhjal töötas muuhulgas välja uue kivikirstkalmete kronoloogia. Erinevalt eelnevast, Vello Lõugase käsitlusest, milles mängisid olulist rolli kalmete ehituslikud iseärasused ja matmisviis, lähtus Lang eeskätt esemelisest leiuainesest. Kui Lõugase järgi tuli Pirita jõe alamjooksu kivikirstkalmed dateerida paari sajandisse enne ajaarvamise vahetust, siis Lang paigutas enamiku kalmistutest 600./500. ja 300./200. aasta vahele $\mathrm{Kr}$ ning ühe rühma ka ajavahemikku 800-500 eKr.

Et kivikirstkalmed on suhteliselt leiuvaesed ega sisalda suletud leiukomplekse, on viimasel kümnendil nende dateerimisel kasutusele võetud luude radiosüsinikuanalüüs. Vaatamata sellele, et kõige tulemuslikum seejuures on tervete kalmerühmade hõlmamine ja et Pirita jõe alamjooksul on selliseid tervenisti või suures osas läbi kaevatud kalmistuid rohkem kui kusagil mujal Eestis, on siinsed kivikirstkalmed 
nendest uuringutest enamjaolt välja jäänud: kas pole enam kui sajanditagustel kaevamistel luid kogutud või olid kalmed liiga lõhutud, luud uude hoidlasse kolimise ootel ligipääsmatult pakitud või niigi pealiskaudsed kaevamis- ja osteoloogilised andmed vastuolulised. Viimane tegur on osutunud luuproovide kogumisel ootamatult tõsiseks takistuseks. Suure osa piirkonna kivikirstkalmetest kaevas läbi Vello Lõugas, kelle vastavate tööde kohta on enamasti olemas vaid pealiskaudsed ülevaateartiklid; aruanded tavaliselt puuduvad. Osteoloogilised eksperdiandmed, kui need on olemas, piirduvad Leiu Heaposti poolt jämedalt kolme vanuserühma jaotatud maetute loeteluga. Proovide kogumisel juhtus mitmel korral, et luukogu koosseis ja/või korraldus ei vastanud ei väljakaevaja ega osteoloogi kirjeldusele. Selline olukord tähendab, et radiosüsinikudateeringutele ei pruugi saada usaldusväärseid kontekste ja tekib oht toota infomüra või koguni valeandmeid. Mainitud juhtumid lahenesid nii, et planeeritud proovid jäid võtmata või õnnestus olemasolevate infokildude (sh osteoloogi avaldamata andmete) alusel luustike paiknemisest enamvähem tõenäoline pilt rekonstrueerida. Edaspidi võib selliste olukordade osaliseks lahenduseks olla täiemahuline ja üksikasjalik osteoloogiline analüüs, aga ka siis võib kaevamisaruandluse puudumine tekitada olukorra, kus luu(stiku) asukoht kalmes või isegi kalmistus jääb teadmata. Samalaadne vastuolu väljakaevaja, hilisema uurija ning füüsilise leiukogu vahel on mõnikord täheldatav ka keraamikaleidude puhul.

Neil põhjusil on kõnealuses piirkonnas radiosüsinikumeetodil suhteliselt esinduslikult analüüsitud ainult Väo Jaani kalmed, mille 15 dateeringut on avaldatud eraldi artiklis (Laneman et al. 2015). Iru 14., Väo Pärna 1. ning Väo Kangru 1. ja 8. kalmesse maetud mehed, igast kalmest üks, dateeriti vana DNA uuringu käigus (Saag et al. 2019). Iru 18. ja Kuristiku 4. kalmest on kummastki dateeritud 4-5 inimest, st enamik maetutest, aga tõenäoliselt mitte kõik. Need andmed ei ole varem publitseeritud. See teeb kõnealuse piirkonna kivikirstkalmete kohta kokku 28 radiosüsinikumäärangut, millest üle poole tuleb Väo Jaani kalmistust. Käesoleva artikli eesmärk on avaldada Iru 18. ja Kuristiku 4. kalme dateeringud, koondada varem avaldatu ning analüüsida lisandunud andmeid, sh nende sobivust seni prevaleerinud kronoloogia ja dateerimisprintsiipidega.

Olukorras, kus kivikirstkalmete rühm koosnes 4-10 kalmest ja igas kalmes oli mitu surnut, kuid dateeritud on ainult kas üksikuid kalmeid või luustikke, saavad järeldused mõistagi olla väga piiratud ulatusega. Saab väita, et radiosüsinikumäärangute põhjal otsustades rajati Iru ja Väo Kangru kalmistud kõige hiljem ajavahemikus 1100-900 eKr, Väo Pärna ja Kuristiku rühmad hiljemalt 900-800 eKr ning Väo Jaani kivikirstkalmed hiljemalt 800-550 eKr. Kõige hilisemate kirstusiseste luustike radiosüsinikumäärangud (Iru 18. ja Kuristiku 4. kalmes) on kohakuti kalibreerimiskõvera platooga, st tulemuseks on pikaleveniv ajavahemik 800-400 eKr. Kuna selliste dateeringute täpsustamiseks antud juhtudel muid võimalusi pole, siis tuleb praeguste väheste andmete juures tõdeda, et kirstudesse võidi matta kuni 400. aastani eKr. Ei saa välistada, et tegelikult lõppes kirstudesse matmine (ja uute kalmete lisandumine) märgatavalt varem, ega ka seda, et tulevikus võidakse mõnest kirstust tuvastada nimetatud daatumist hilisem matus. Kivikirstkalmete üldine 
dateering 1100. ja 400. aasta vahel eKr on aga igati kooskõlas teistest piirkondadest saadud radiosüsinikuandmetega. Iru 18. ja Väo Jaani kalmetes leidus ka ajavahemikku 400-200/100 eKr dateeritud (tõenäoliselt kirstuväliseid) luustikke, mille puhul ei saa kindlalt öelda, kas need tähendavad kalmistu järjepidevat kasutamist pronksiajast rauaaega või eraldi episoodi peale mõnesajandilist katkestust matmises. Väo Jaani kalmeis tuvastati ka selliseid luid/luustikke, mille ${ }^{14} \mathrm{C}$-dateeringud jäävad ajavahemikku 50-650 pKr ja mis tõenäoliselt ei ole järjepideva matmise tulem. Ka tundub suurem osa sel ajal maetuid olevat lapseealised, mis tähendab, et kogukonna ülejäänud liikmed maeti mujale. Kuristiku 4. kalmes, kus äärevarest leiti luud koos 4.-5. sajandi käevõrudega, ei leidnud hüpotees rooma rauaaegsetest matustest kinnitust.

Radiosüsinikudateeringud on senistest, peaasjalikult esemetüpoloogiatel põhinevatest ajamäärangutest sadu aastaid varasemad. Ühelt poolt tuleb märkida, et radiosüsinikudateeringute puhul ei ole (magevee) reservuaariefekti välistatud, mistõttu võivad dateeritud luud tegelikust märksa vanemad näida. Teisalt on võrdlemisi hästi dateeritav Väo Kangru ornamendiga pronksnuga ${ }^{14} \mathrm{C}$-andmetega heas kooskõlas ja osutab pigem nende usaldusväärsusele. Tähtis on ka arvesse võtta, et ülejäänud leiuaines on napp, fragmentaarne ning suletud leidude ja lähedaste analoogide puudumisel hoopis raskemini dateeritav, mis asetab vastavad katsed paratamatult ebakindlale alusele ega võimalda radiosüsinikuandmeid ei täpsustada ega vaidlustada. Peamised leiud kõnealustes kalmetes olid - Langi tüpoloogia kohaselt - 3. variandi labidaspäised luunõelad ja BII:b tüüpi keraamika, mis dateeriti pronksiaja kõige viimasesse otsa ja varasesse eelrooma rauaaega eeskätt seetõttu, et neid ei esinenud koos Põhjala pronksiaja IV ja V perioodile iseloomulike pronksesemetega ning pronksiaja lõppu dateeritud kindlustatud asulateski leidus neid vähe. Oma osa kalmerühmade dateerimisel eelkõige eelrooma rauaaega oli (tõestamata) eeldusel, et panusteta kalmed on panustega kalmetest hilisemad, ning arvatavasti ka Eesti arheoloogias pikalt valitsenud veendumusel, et kivikirstkalmed on eelkõige eelrooma rauaaegne nähtus. Praeguseks on kogunenud andmeid, et mainitud keraamika - mille järgi dateeriti mainitud nõelad - võib ulatuda märksa varasemasse aega (ehkki selle kronoloogia on endiselt pigem ebaselge). Ka võib keraamikatüübi puudumisel teatud tüüpi muististes olla muid põhjusi peale kronoloogiliste. Märkida tuleb sedagi, et kirstudes leidub savinõusid tegelikult harva ja kalme dateerimine kirstuvälise keraamika järgi on mitmel põhjusel küsitav. Labidaspeaga luunõelte tüüpide kronoloogiline erinevus on uute andmete valguses samuti kaheldav.

Kivikirstkalmete varasemaks nihkuvad dateeringud tähendaksid seda, et kui senise käsitluse kohaselt tekkis suurem osa kivikirstkalmistuid ajal, mil nn kindlustatud asula aeg Irus oli lõpule jõudmas või jõudnud, siis nüüd paistavad kivikirstkalmed kas asulast varasemad või sellega samaaegsed. Nende kronoloogilist suhet on raske määratleda, sest asula praegu prevaleeriv dateering $800-500 \mathrm{eKr}$ põhineb suuresti Hallstatti platoole langevatel söedateeringutel ning on pelgalt "kokkuleppeline", st asula tegelik eksisteerimisaeg osutatud ajavahemiku piires ja võib-olla ka ümber ei ole teada. Igal juhul on mõeldav ka selline stsenaarium, kus 
asula ja kalmed tekkisid ja/või jäeti maha enam-vähem samal ajal. Pronksivalu ja -kaubandusega tegelenud asula ja ümbruskonna kalmete sünkroonsus võib osutada sellele, et pronksikaubanduse hääbumine või ümberorganiseerimine võis vähemalt rannikuala rahvastikule seni arvatust suuremat mõju avaldada. Lõpuks tuleb aga ka tõdeda, et kui kronoloogia on ebaselge, siis saab arheoloogilist ainest igasugustele tõlgendustele sobivaks painutada. 